insist upon as regards belief, science declines to accept finality in the position of natural knowledge at any epoch, or to construct a standard which all discoverers must follow. As Huxley said, when unveiling Darwin's statue in the Natural History Museum, South Kensington, in 1885 , science " commits suicide when it adopts a creed."

We need scarcely say that it is not our wish to have a discussion in NATURE upon Genesis and modern science, or religious belief and scientific evidence. Our sole object in taking up the subject of the prohibition of the teaching of evolution in certain States of the United States, and in inviting opinions upon this action from a number of leading authorities, has been to afford support to our colleagues fighting for scientific truth and progress against dogma and stagnation. We trust that the additional messages subjoined will give them the strength and courage they need to secure for them the position of intellectual freedom established in Great Britain many years ago, and existing unchallenged to-day.

Prof. J. George Adami, M.D., F.R.S., Vice-Chancellor of the University of Liverpool.

Notwithstanding "Main Street," it is difficult for us in the old country to realise the state of public opinion throughout the greater part of the United States outside the larger cities : difficult to realise how the minister (be he Methodist or Baptist, Congregationalist or Lutheran) and the Sunday School dominate the community. In the small country town-and every village aspires to be a town-there is no society, and no public opinion, save that centring round one or other church. He is out of society who is not a church member, and it is a commonplace for "Aunt Susan," a representative of one of the oldest families in the town, to conduct the Sunday School class, she being close upon seventy, and her class consisting of the elderly farmers of the locality and their wives and associated elderly spinsters, who have, as it were, grown up under her wing. Visit the farms and other houses of the town and you will find no solid literature that is not theological of an approved type, and of that but some three or four books. Read the local papers and you will see in them little beyond local news, of church teas and picnics, of auctions, of local weddings and funerals in most intimate detail, with a long column of notes upon the doings of local personages, how this one has left for New York or that one returned from Chicago, with, of course, full information regarding local and league doings in baseball. They contain absolutely no news about the outer world, no discussion of topics outside the range of the Sunday School. Save personal gossip and local happenings, all other topics are taboo.

The "Aunt Susans" and their elderly classes in their turn dominate the minister. For his peace of mind-and bread and butter-he dare not venture beyond the bounds of the teaching delivered over long years by Aunt Susan. All the leaders of the community would be scandalised and up in arms. They pay him, and he has no security of tenure. As a consequence an intellectual stagnation and aridity, a narrowness of outlook and a supreme confidence that opinion in Pumpkin Corner is the only possible and only right opinion, unbelievable as they are to us, are actualities throughout Tennessee and agricultural North America.

It is this that makes possible and that explains the proceedings which have led to the Dayton trial. It is this state of affairs that explains the lack of theological progress which in itself is adequate to explain the situation in Tennessee, Oklahoma, Florida, and many other States.

It is eminently likely that in the trial at Dayton the arguments for and against evolution will not be reached. There is a matter yet more fundamental, politically speaking, than that upheld by the Fundamentalists, namely, the constitutional right to fetter liberty of thought. It is a question of supreme moment whether in the "Land of Freedom" the Tennessee decision does not contravene the Declaration of Independence and the basal right of every citizen of the United States to a reasonable liberty.

Prof. C. Lloyd Morgan, D.Sc., F.R.S., Emeritus Professor of Psychology, University of Bristol.

Through the courtesy of the Editor of Nature I am permitted to enrol my name among those who wish to express their sympathy with advocates of the free and untrammelled spread of evolutionary teaching throughout the length and breadth of the United States of America.

I am one of those who believe that all advance in the order of Nature of which we ourselves, body and mind, are constituent parts exemplifies evolutionary progress. This may be true or it may be false. If it be true, no legislative authority can suppress it ; if it be false, it will not be through legislative authority that its falsity will be demonstrated.

But I am also one of those who believe that there are thousands in America and elsewhere who find.in evolution a stay and support of their deepest religious convictions. If this be so-if, as I think, it be plain matter of history vouched for by these thousands of religious people-the position, as I see it, is this : by excluding evolutionary teaching in the schools and colleges of this or that State, an avenue to the full and free development of religious faith and observance is arbitrarily barred by legislative enactment.

Unless those who attend these schools and colleges differ markedly from those young folk with whom I have been for many years acquainted in England, there will always be a certain percentage who will find that the form of theological doctrine, whatever it may be, that is prescribed under authority is such as they cannot honestly accept. In my experience a large proportion of these honest and perplexed young people scarcely know what evolution means. When they have learnt what light it may throw on the problems that perplex them, they rejoice in their new sense of freedom from the bondage that has been enforced by authority.

\section{The Right Rev. H. Hensley Henson, Lord Bishop of Durham.}

IT is difficult for an educated Englishman, and $a$ fortiori an educated English clergyman, to regard the proceedings in Tennessee without astonishment and contempt. The scientific theory of evolution, popularly associated with the name of Charles Darwin, has

No. 2907, voL. I I 67 